\title{
ANALISIS PERKEMBANGAN SISTEM INFORMASI MANAJEMEN UNTUK DUNIA PENDIDIKAN DAN PERUSAHAAN
}

\author{
ALIF SAUM RIZALITAHER
}

\author{
Prodi Sistem Informasi,Fakultas Sains Dan Teknologi,UINSU
}

alisaum21@gmail.com

\begin{abstract}
Abstrak
Perkembangan SIM sangat pesat dalam bidang teknologi sehingga memaksa perusahaan dan pendidikan harus mengngikuti perkembangannya.Tanpa adanya informasi kita tidak mungkin bisa maju melawan zaman yang serba modern ini. sebab itulah SIM sangat penting bagi dunia pendidikan dan perusahaan. Baik dari luar maupun dari dalam.Semua mencangkup hubungan antara satu dengan yang lainnya.Banyaknya tersedia perangkat lunak memudahkan dalam kegiatan pendidikan dan perusahaan.Pada artikel ini bertujuan menganalisis hasil perkembangan SIM dari tahun-ketahun.Diaharapkan dapat menjadi sumber informasi yang baik dan mendukung perkembangan Sistem Informasi Manajemen.
\end{abstract}

Katakunci: Sistem informasi manajemen, Sistem, Informasi, pendidikan , perusahaan, perkembangan

\section{PENDAHULUAN}

Tuntutan perkembangan Sistem Informasi membuat informasi menjadi sebuah kebutuhan.perkembangan ini juga membuat peran manajer menjadi berubah. dengan menigkatanya pertembuhan teknologi informasi membuat aktivfitas menjadi akurat dan tepat waktu.para manajer juga mudah dalan menganalisis kinerjanya dengan pemanfaatan teknologi informasi

Mungkin pada awalnya Sistem Informasi Manajemen tidak menggunakan teknologi,tanpa disadari
Sistem Informasi manajemen sudah di lakukan tanpa menjadi sebuah ilmu pengetahuan.namun seriiring dengan perkembangan zaman Sistem Informasi Manajemen menjadi tidak mungkin apabila tidak adanya teknologi.SIM mulai menjadi sorotan di bidang pendidikan dan usaha.

Dari tahun ke tahun pertumbuhan Sistem Informasi semakin bertumbuh pesat, mudahnya dalam mendapatkan sebuah informasi.Dengan meningkatnya kebutuhan tentang informasi,membuat sebuah informasi menjadi lebih berkembang. 


Sistem informasi berfungsi
Mempermudah pihak manajemen
dalam melakukan pengawasan,
perencanaan, pengarahan serta kinerja
pada semua unit yang mempunyai
hubungan.Meningkatkan kualitas SDM
sebab unit sistem kerja akan lebih
terkoordinasi dan sistematis.
Meningkatkan efesiensi data yang lebih
akurat dan tepat waktu. Meningkatkan
produktivitas serta menghemat biaya di
dalam organisasi.oleh karena itu sistem
informasi manajemen berdampak besar
pada bidang pendidikan dan perusahaan

\section{STUDI LITERATUR}

Studi literatur telah penulis lakukan dengan cara mengumpulkan sebagian informasi dari jurnal, makalah, dan buku tentang perkembangan sistem informasi manajemen yang berasal dari internet.Pengumpulan data ini dilakukan dengan cara menyaring berdasarkan fakta yang telah di tentukan oleh penulis dari setiap informasi yang di ambil.

\section{METODE PENELITIAN}

Jenis penelitian pustaka(library research)digunakan pada peneltian ini.Yaitu kegiatan yang berhunbungan dengan pengumpulan data,mencatat dan membaca,serta metode pengolahan bahan.

Selanjutnya data di kelompokan dari dokumen, karya ilmiah, serta berbagai artikel yang berkaitan dengan perkembangan sistem informasi manajemen.

\section{PEMBAHASAN}

\section{Pengertian}

a.Sistem

Sistem secara umum ialah sebuah kumpulan objek-objek atau seluruh bagian atau seluruh unsur yang mempnyai arti yang berbeda-beda dan saling menyatu, saling memengaruhi dan juga saling berkerjasama satu dengan yang lainnya serta juga memiliki keterikaitan pada sebuah rencana yang sama agar mencapai sebuah tujuan tertentu dalam sebuah lingkungan yang kompleks.

Sistem secara terminolog
dipergunakan dengan bermacam
macam cara yang sangat luas.Sehingga
sulit untuk mengartikan dan mendefinisikannya sebagai sebuah pernyataan dalam mencangup semua kegunaannya dan juga cukup ringkas untuk bisa memenuhi syarat yang sudah menjadi maksudnya.Beberapa $\mathrm{Hal}$ demikian disebabkan oleh pengertian dari sistem itu bergantung oleh latar belakangnya seseorang yang mencoba untuk mendefinisikannya. contohnya, menurut hukum bahwasannya Sistem dilihat sebagai suatu kumpulankumpulan aturan yang membatasi, dari segi kapasitas sistem sendiri maupun lingkungan sistem itu sedang berada untuk menyediakan jaminan keadilan dan keserasian.

b.Informasi

Pengertian Informasi menurut Jogiyanto (2005) adalah "Informasi diartikan sebagai data yang diolah menjadi bentuk yang lebih berguna dan lebih berarti bagi yang menerimanya" .

Pengertian Informasi menurut Kusrini (2007) adalah "Informasi adalah 
data yang sudah diolah menjadi sebuah bentuk yang berguna bagi pengguna yang bermanfaat dalam pengambilan keputusan saat ini atau mendukung sumber informasi".

Pengertian Informasi menurut McLeod (2005) adalah "Data yang telah diproses, atau data yang memiliki arti".

Pengertian Sistem Informasi menurut Husain dan Wibowo (2002) ialah "Sistem Informasi adalah seperangkat komponen yang saling berhubungan berfungsi sebagai memproses, menyimpan mengumpulkan, dan mendistribusikan informasi demi mendukung pembuatan pengawasan dan keputusan dalam organisasi".

c.Sistem Informasi Manajemen

Demikian itu,Sistem Informasi Manajemen disimpulkan dengan sistem pada sebuah organisasi yang memberikan informasi untuk kebutuhan organisasi tersebut.

Beberapa Pengertian Sistem Informasi Manajemen Menurut para Ahli

1. Menurut Gordon B. Davis Sistem Informasi Manajemen adalah sistem manusia atau mesin yang menyediakan informasi untuk mendukung operasional manajemen dan fungsi pengambilan keputusan suatu organisasi.

2. Menurut James O'Brien: kombinasi setiap unit yang dikelola oleh pengguna (manusia, jaringan komputer, perangkat keras dan lunak, dan lainnya) yang mengumpulkan, mengubah, dan menyebarkan informasi tentang organisasi.
3. Menurut Barry E.

Cushing: suatu sumber daya modal dan manusia pada organisasi yang bertanggung jawab untuk mengumpulkan dan mengolah data agar menghasilkan informasi yang berguna untuk semua tingkatan manajemen dalam aktivitas perencanaan dan pengendalian.

4. Menurut McLeod dan Schell: sistem berbasis komputer yang mampu menyajikan

Berikut Komponen dari Sistem Informasi Manajemen

Semua komponen bekerja sama untuk menyediakan informasi yang tepat waktu dan layak.komponen ini merupakan komponen komponen utama dalam Sistem Informasi Manajemen.

Adapun komponen-komponen sistem informasi tersebut yaitu :

a. Prosedur

Prosudur berfungsi sebagai petunjuk manusia bisa menggunakan sistem informasi secara luas. Prosudur dapat membantu manusia dalam mempermudah kegiatan Sistem Informasi manajemen.

\section{b.Manusia}

komponen-komponen dijalankan oleh manusia.komponen tersebut bergerak atas kemauan dan kehendak manusia.manusialah yang mengontrol semua aktifitas Sistem Informasi manajemen

c. Data

Data merupakan sebuah istilah yang menunjukkan kepada fakta dari sebuah topik. Data berarti suatu 
pernyataan yang di terima apa danya Data dapat dirubah menjadi sebuah informasi yang sangat berharga.fakta yang dikumpulkan untuk menjadi data,kemudian di utarakan secara jelas dan tepat.

\section{d. Hardware}

Hardware atau perangkat keras adalah komputer yang dijalankan menggunakan Software.Sudah banyak komputer yang canggih yang dapat membantu manusia dalam menjalankan kegiatan manajemen.

\section{e. Software}

Software atau perangkat lunak digunakan utuk menjalankan perangkat keras.Software sendiri berupa aplikasi dan sistem operasi.Perintah-perintah manusia kepada Software kemudian di jalankan kepada Hardware.Sebuah manajemen yang baik memiliki Software yang tingkat keamanannya baik pula.

\section{Sistem Informasi Manajemen Di Masa Lalu}

Samuel Morse, mendeklarasikan sistem komunikasi telegraf untuk pertama kalinya di Morristown, New Jersey 6 januari 1838. Telegraf merupakan perangkat yang menggunakan impuls listrik untuk mengirimkan pesan yang dikodekan melalui kabel.

Temuan besar ini mampu merevolusi komunikasi jarak jauh dan mencapai puncak popularitasnya pada tahun 19201930.

Melansir History, ide pembuatan telegraf muncul di usia Morse yang masih relatif muda, kala ia mendengar tentang elektromagnet yang baru ditemukan pada tahun 1832. Morse pun menghabiskan tahun-tahun berikutnya untuk mengembangkan idenya itu bersama dua rekannya, Leonard Gale dan Alfred Vail.Pada 1838, ia mendemonstrasikan penemuannya menggunakan sandi morse, kode berupa titik dan garis yang mewakili huruf dan angka.

Pada tahun 1928 di Jerman,Pita magnetik digunakan sebagai media penyimpanan, perangkat tersebut dinamakan tape drive. Tape drive dapat merekam audio, merekam vidio dan dapat di putar ulang. Sehingga dapat dilihat berulang ulang kali dimanapun dan kapanpun. Perangkat ini sudah tidak digunakan lagi pada zaman sekarang dkarenakan terdapat perangkat yang lebih canggih

Tape Drive menguncang industri penyiaran dan reproduksi suara menjadi lebih maju. Tape Drive memungkinkan siaran langsung dapat di rekam dan di putar ulang. Sehingga rekaman rekaman musik bisa di edit agar kualitas suara menjadi lebih bagus. Tape drive membuat perkembangan teknologi komputer awal menjadi lebih maju. Sehingga dapat menyimpan jumlah data yang begitu banyak secara mekanisme,diakses begitu cepat, dan disimpan dalam waktu yang lama. Tape Drive adalah salah satu teknologi yang menguncang peradaban kemajuan komputer pada masa saat itu sayangnya sudah tidak digunakan lagi.

Vannevar Bush (11 Maret, 8190 - 30 Juni), pada tahun 1974 adalah seorang insinyur dan ilmuwan berkebangsaan Amerika yang terkenal karena keberhasilannya pada bidang kompetisi analog,serta peran politiknya pada pengembangan bom atom, dan idenya tentang Memex, yang dilihat sebagai konsep awal munculnya 
teknologi World Wide Web. Memex (singkatan dari "memory extender"), adalah sebuah nama yang telah diberikan oleh Vannevar Bush untuk sebuah mesin teoretis miliknya yang ia usulkan dalam artikel As We May Think, yang dimunculkan pada tahun 1945 pada The Atlantic Monthly. Memex disebut juga sebagai pembuka jalan dari teknologi hiperteks yang saat ini telah digunakan.

Vanner Bush tidak terkait dalam perkembangan internet secara langsung, namun penemuannya mempengaruhi kemajuan teknologi di masa sekarang. Sebuta "God Father Word Web" diberikan kepada Vanner Bush. Dalam artinkelnya "AS WHY MY THINK" beliau menyebutkan mesin penemuannya yang disebut MEMEX. Mesin tersebut dapat menigkatkan memori manusia dengan cara menyimpan dan mengambil dokumen dalam sebuah kumpulan data. Perangkat tersebut sama dengan hypertext yang di kenal pada saat ini. Hypertext digunakan dalam penyimpanan sebuah website utuk membuat sebuah halaman website.

\section{Perkembangan Sistem Informasi Manajemen Pada Perusahaan}

Bisnis sistem dalam bidang IT pertama kali terbuat ketika CERN dalam menanggulangi biaya operasionalnya memungut bayaran dari anggotaanggotanya. Tahun 1992 pembentukan komunitas internet, kemudian diperkenalkanlah sebuah istilah World Wide Web (WWW) oleh CERN.Pada tahun 1993, NSF membentuk interNIC untuk menyajikan jasa pelayanan internet menyangkut hal direktori dan penyimpanan data serta database oleh AT\&T, jasa registrasi oleh Network
Solution Inc,dan jasa informasi oleh General Atomics/CERFnet. Tahun 1994 internet berkembang dengan cepat dan telah memasuki segala aspek kehidupan manusia. Teknologi menjadi salah satu yang tidak bisa di lepas dari kehidupan manusia. Tahun 1995, sudah banyak perusahaan yang telah menyediakan provider dengan membeli jaaringan backbone. Ini telah Membuat perkembangan teknologi Khususnya pada bidang informasi menjadi lebih mudah dan cepat menyebar luas berkat adanya penelitian untuk alat yang lebih canggih lagi.

Berikut beberapa sistem informasi manajemen yang di pakai perusahaan:

Enterprise Resource Planning (ERP) adalah konsep pengelolaan sumber daya organisasi. Sumber daya dapat digunakan secara semestinya dan dapat di optimalkan. Sumber daya tersebut terdiri dari dana, waktu, material organisasi. Sumber daya yang baik dapat membuat organisasi menjadi stabil.

\section{Enterprise Resources Planning}

(ERP) adalah sistem informasi pada sebuah organisasi yang berjalan di bidang manufaktur dan jasa yang berperan menggabungkan proses bisnis dengan aspek produksi,operasi hingga distribusi sebuah organisasi tersebut. ERP secara otomatis mengatur pekerjaan sebuah perusahaan.

Konsep ERP ini bertujuan untuk menggabungkan sistem yang sebelumnya yang telah terpisah dalam sebuah perusahaan, misalnya proses produksi, pemesanan bahan mentah, sampai proses pendistribusian.

Keberhasilan konsep ini dipengauhi oleh ketersediaan teknologi 
yang memadai. Sebuah perusahaan harus memiliki perangkat yang cukup demi mamadai konsep Enterprise Resources Planning.

Hal ini disebabkan oleh konsep dari ERP sebagai aplikasi yang didalamnya tedapat modul-modul kerja. Aplikasi tersebut digunakan untuk mengelola database perusahaan dengan efisien dan efektif. Databe tersebut menyimpan data data sebuah perusahaan.

Tujuan ERP adalah untuk mengintegerasi data untuk seluruh area di sebuah organisasi, menyatukan data data tersebut agar mudah di atur dan di akses kenerjanya. ERP melakukan integrasi dengan cara menyatukan data pada sebuah database untuk di gunakan pada software, maksudnya software memiliki peran masing masing pada fungsi bisnis yang berbeda. Sehingga manajemen dapat dengan mudah mengatur fungsi fungsi berbagai macam software sesuai dengan fungsinya masing masing.

\section{supply}

chain

management (SCM) adalah pengelolaan sebuah alur produksi barang maupun jasa yang dimulai dari bahan dasar sampai pengiriman produk akhir ke pelanggan.

SCM dijalankan dengan membuat rantai pada supplier dengan yang lainnya,kemudian di berikan ke pabrik untuk di olah. Setelah di olah produk di edarkan oleh pihak yang bertugas ke pada masyarakat umum

Tanpa SCM perusahaan akan berjalan begitu saja tanpa adanya perhitungan yang justru dapat merugikan perusahaan itu sendiri.
Supply

chain management terdiri dari perencanaan, pengawasan, dan eksekusi di masingmasing tahapan.

Dengan dikelolanya hal hal tersebut, pelaksanaan manajemen menjadi lebih mudah dan efisien

Sehingga dapat dipastikan dan mengetahui apakah produk yang di buat sudah sampai ke tangan pelanggan yang tepat.

Transaction Processing System (TPS) merupakan Sistem Informasi yang digunakan untuk mengelola data dalam jumlah yang begitu besar untuk tansaksi bisnis seperti gaji dan inventarisasi.TPS mengurangi waktu saat melakukan transaksi operasional, meskipun data yang dimasukkan harus secara manual kepada sistem komputer. Sistem ini dapat menghapus rasa bosan akibat terlalu lama menunggu.

Transaction Processing System merupakan sistem tanpa batas sehingga perusahaan dapat berkomunikasi di lingkungan luar. Karena data data informasi diperbarui setiap menit sjalan dengan yang terjadi di perusahaan. Dimana hal tersebut berguna bagi manajer agar lancar dalam operasi bisnis tanpa adanya penyelaan. Dengan begitu pekerjaan manajer menjadi lebih mudah, cepat, dan tidak terkendala oleh waktu.

Seiring Perkembangan teknologi Transaction processing systems (TPS) telah berkembang menjadi otomatis dan elektronik yang dulunya memakai sistem manual dalam memproses data. Sehingga dalam prosees Transaction processing systems mencatat dan memproses data hasil dari transaksi 
bisnis, seperti penjualan, pembelian, dan perubahan persediaan/inventori.

Transaction processing systems menghasilkan informasi produk contohnya,TPS membuat cek gaji karyawan, formulir pajak, rekening keuangan, kuintansi penjualan, orden pembelian dan lain sebagainya. TPS juga memperbarui data data perusahaan untuk di proses dalam Sistem informasi manajemen. Sehingga data tersebut dapat di proses secara baik dan benar.

DECISION SUPPORT SYSTEM (DSS) merupakan salah satu produk perangkat lunak yang dikembangkan secara khusus untuk membantu manajemen dalam proses pengambilan keputusan (Indrajit 2001, p.179). Sesuai namanya, tujuan digunakannya system ini adalah sebagai "second opinion" atau "information source" yang dapat dipakai sebagai bahan pertimbangan sebelum seorang manajer memutuskan kebijakan tertentu.

DSS sering di rancang untuk menggunakan teknik simulasi yang interaktif. Sehingga sistem dapat menyajikan keadaan dunia bisnis yang nyata dan sebenarnya. Teknik ini dapat menarik minat manajer agar kiranya manajer dapat menggunakan DECISION SUPPORT SYSTEM. Teknik ini termausuk sering digunakan pada perancangan DSS.

DSS tidak digunakan untuk menggantikan tugas menajer, melaikan membantu tugas manajer. Sehingga manajer dapat leih mudah dalam menjalankan tugas tugasnya.DSS sebenarnya merupakan pelaksanaan teori-teori pengambilan keputusan yang telah diperkenalkan oleh ilmu-ilmu seperti operation research dan management science. Hanya bedanya adalah bahwa jika dahulu untuk mencari penyelesaian masalah yang dihadapi harus dilakukan perhitungan iterasi secara manual (biasanya untuk mencari nilai minimum, maksimum, atau optimum),Sekarang komputer lah yang melakukan tugas dan persoalan yang sama dengan lebih cepat dan efisien.Sehingga tugas manajer menjadi lebih mudah.

\section{Peran Sistem Informasi Manajemen Pada Pendidikan Sekarang}

Dimasa pandemi ini, peran sistem informasi manajemen pendidikan sangatlah signifikan yaitu; SIM dapat meningkatkan aksebilitas data yang tersedia secara tepat waktu dan akurat bagi para pemakai, tanpa mengharuskan adanya perantara dari sistem informasi yang ada; SIM membantu mengembangkan proses perencanaan yang lebih efektif dan efisien; SIM dapat mengantisipasi serta memahami konsekuensi ekonomis baik dari sistem informasi dan teknologi baru yang berkembang; Sekolah dapat menggunakan sistem informasi untuk dapat mengolah data transaksi, mengurangi biaya dan memberikan pendapatan sebagai suatu produk pelayanan; SIM dapat menganalisis suatu kebutuhan-kebutuhan informasi yang diperlukan; SIM sebagai pengendalian manajemen adalah untuk mengukur pekerjaan, memutuskan tindakan pengendalian, merumuskan aturan tentang keputusan baru untuk diterapkan pada personalia operasional, serta mengalokasikan sumber daya yang telah tersedia. Hal itu berarti peran sistem informasi manajemen pendidikan di masa pandemic ini sangatlah sentral.

Peran SIM pendidikan di masa pandemi yang sangat terlihat jelas 
adalah pada manajemen kurikulum/ pembelajaran. Perubahan dari pertemuan tatap muka didalam kelas, kepada pertemuan menggunakan media elektronik tidak bisa dianggap sepeleh. Jika salah mengambil langkah, bisa-bisa pembelajaran tidak bisa berjalan dengan baik. Salah satu sarana SIM pendidikan di masa pandemi ini adalah E-Learning. Didalam E-Learning, terdapat interaksi antara guru dan murid, seperti pembelajaran pada umumnya. Namun, yang sedikit berbeda adalah, semua hal yang berkaitan dengan pembelajaran harus diunggah ke sistem Elearning, seperti daftar hadir, tugas harian, materi pembelajaran, dan penilaian harian. Sehingga, lembaga pendidikan membutuhkan SIM pendidikan yang cukup tangguh untuk meng-cover semua kebutuhan pendidik dan peserta didik saat proses belajar mengajar.

\section{Dampak Dari Perkembangan SISTEM INFORMASI MANAJEMEN}

Seperti yag sudah di jelaskan Sistem Informasi sangat berperan penting.untuk itu kita harus mengetahui dampak dampak yang diakibatkan oleh SIM dampak tersebut akan dipaparkan sebagai berikut.

Penerapan SIM dapat
emberikan manfaat diantaranya
mempermudah perusahaan dalam
menjalankan fungsi manajemen
diantaranya perencanaan, pengawasan,
dan pengambilan keputusan.Dengan
meningkatnya Perkembangan SIM dapat
membuat fungsi manajemen menjadi
lebih efektif dan efisien.

Proses tersebut dikarenakan data yang dibutuhkan dapat di peroleh secara on time dan akurat. Dengan bantuan alat yang lebih canggih mempermudah kinerja SIM lebih stabil dan terkendala.

Manfaat lainnya yaitu meningkatnya kualitas sumber daya manusia dan sumber daya lainnya yang dapat mendukung sebuah organisasi.

Menghematnya anggaran
organisasi dan meningkatnya
produktifitas juga merupakan manfaat dari perkembangan Sitem Informasi Manajemen

Namun perkembangan SIM juga memiliki dampak yang negatif seperti bertambahnya angka pengangguran. Penerapan SIM secara besar besaran dapat menyebakan hilangnya pekerjaan yang seharusnya dilakukan oleh mausia kini telah tergantikan oleh teknologi sebagai bagian dari sistem informasi manajemen

Tidak itu saja,masalah keamanan data yang rentan berdampak sistematis juga berpengaruh. Dikarenakan salah satu hal yang penting adalah data maka organisasi menyimpan data dalam sebuah database. Apabila seseorang yang tidak bertanggung jawab meretas atau membobol database tersebut. Sehingga menimbulkan masalah ekonomi yang sistematis dan berdampak luas.

Mudahnya proses manajemen yang dilakukan dengan penerapan Sistem Informasi Manajemen dapat mengakibatkan manusia menjadi malas dan cenderung mencari jalan pintas. Kemampuan berpikir yang rasional dan hanya mengandalkan kemampuan dari sistem sebagai sat satunya solusi terhadap masalah yang dihadapi 


\section{KESIMPULAN}

Sistem informasi manajemen atau SIM adalah sistem perencanaan bagian dari pengendalian internal suatu bisnis yang meliputi pemanfaatan manusia, dokumen, teknologi, dan prosedur oleh akuntansi manajemen untuk memecahkan masalah bisnis seperti biaya produk, layanan, atau suatu strategi bisnis.

Fungsi SIM sendiri yaitu
Mempermudah pihak manajemen dalam melakukan pengawasan, perencanaan, pengarahan serta kinerja pada semua unit yang mempunyai hubungan.Meningkatkan kualitas SDM sebab unit sistem kerja akan lebih terkoordinasi dan sistematis. Meningkatkan efesiensi data yang lebih akurat dan tepat waktu. Meningkatkan produktivitas serta menghemat biaya di dalam organisasi.oleh karena itu sistem informasi manajemen berdampak besar pada bidang pendidikan dan perusahaan

Perkembangan SIM di masa lalu sangatlah cepat didorog dengan penemuan penemuan oleh para ahli membuat Sim sangat berkembang cepat. Penemuan-penemuan tersebut sangat berpengaruh pada daunia terutama dalam bidang informasi. Disini dapat kita simpulkan bahwa peran Sistem Informasi berperan penting dalam sebuah kegiatan organisasi.

Sistem Informasi Manajemen di perusahaan terdapat berbagai macam. Oelh karena itu perusahaan harus memilih sistem informasi yang cocok agar perusahaan tersebut dapat berjalan sesuai dengan tujuan. Kemajuan teknologi juga mempengaruhi perusahaan harus membeli alat alat yang baru agar mempermudah kinerja manajemen. Dengan hadirnya alat alat yang cangging tugas manajemen dan penyampaian informasi leih mudah dan tepat waktu.dengan begitu perusahaan harus memiliki banyak pengeluaran agar manajemen bisa membeli alat alat tersebut.

Peran SIM pada pembelajaran pandemi ini salah satunya adalah hadirnya elearning yang dapat membatu guru dan murid bisa belajar tanpa harus tatap muka. Guru dapat mengunggah pelajaran dan tugas di elearning sehingga para murid bisa belajar dari rumah. Sehingga semua materi,daftar hadir, tugas, ujian harus di upload di elearning.tetap terdapat kendala dimana kertika jaringan pada saat tidak stabil mengakibatkan pada saat pengumpulan tugas menjadi terlambat. Juga tidak adanya penjelasan langsung oleh pengajar mengakibatkan murid kurang paham apa yang telah ia pelajari.

Dampak SIM sangatlah banyak,ada yang baik ada juga yang buruk. Tak terlepas dari itu SIM sudah mendarah daging baik dari segi manapun.untuk itu kita harus sigap dalam menaggapi perkembangan kemajuan teknologi.dampak dampak yang sudah di paparkan tadi kiranya bisa memanfaatkan SIM dengan baik dan mencegah terjadinya efek negatif yang disebabkan oleh Sistem Informasi Manajemen.

\section{REFERENSI}

Ridho Saputra, Pengembangan Sistem Rental Kamera Online, Jurnal Pengembangan Teknologi Informasi dan Ilmu komputer Vol.2 No.6 (Juni,2018), hlm. 2221-2226

repository.uin-

suska.ac.id/20698/7/7.\%202018237TM

PI_BAB\%20II 
https://www.gurupendidikan.co.id/pen

gertian-informasi/

Peran Sistem Informasi dan Teknologi Informasi terhadap Proses Pembelajaran di Masa Pandemi Covid-19 Saifan Shodiq Universitas Islam Negeri Jember

https://www.viva.co.id/vstory/teknolog i-vstory/1334047-pengaruh-sistem-

informasi-manajemen-terhadap-

perusahaan

DAMPAK PENERAPAN SISTEM

INFORMASI MANAJEMEN (SIM) DI

SEKOLAH Rivanur Sarah Jurusan Administrasi Pendidikan, Fakultas IImu Pendidikan, UNP

https://getcharintegerina.wordpress.co m/2012/04/19/jenis-jenis-sistem-

informasi-dan-contoh-aplikasinya/

Konsep Dasar Sistem Informasi Dr. Kusnendi, M.S.

Sistem Informasi Manajemen Terhadap Pengambilan Keputusan di Lembaga Pendidikan Islam Ratna Kawuri 185100048p Fakultas Komputer

PENGGUNAAN SISTEM INFORMASI

MANAJEMEN DALAM MANAJEMEN

BERBASIS SEKOLAH DI SDN

MONPASONG ACEH BARAT SKRIPSI

Diajukan Oleh: AMIRUDDIN 271324750

Mahasiswa Fakultas Tarbiyah dan Keguruan Program Studi Manajemen

Pendidikan Islam 